\author{
RAFAŁ MAŃKOํㅜ JAKUB ŁAKOMY²
}

\title{
In search for the ontological presuppositions of critical jurisprudence ${ }^{3}$
}

\begin{abstract}
The aim of the present article is to reflect upon the ontological presuppositions of critical jurisprudence (critical legal science), understood as a set of assumptions in the domain of social ontology, which determine the identity of this form of general reflection upon law. The article proposes to identify four such assumptions: the assumption concerning the political character of the social world; the assumption on the social construction of the social world; the assumption of paninterpretationism; the assumption of the existence of epistemic communities.
\end{abstract}

Keywords: critical jurisprudence, social ontology, the political, social construction of reality, paninterpretationism, epistemic communities

1 Rafał Mańko, PhD - External Fellow, Centre for the Study of European Contract Law, University of Amsterdam; e-mail: r.t.manko@uva.nl; ORCID: 0000-0003-0927-2662.

2 Jakub Łakomy - University of Wrocław; Faculty of Law, Administration and Economics, Head of the Department of the Theory and Philosophy of Law; e-mail: jakub.lakomy@uwr.edu.pl; ORCID: 0000-0002-6655-6787.

3 This article has been prepared as part of the National Science Centre research project No. 2016/21/D/ HS5/03912. 


\section{Introduction}

Apart from traditional legal sciences enjoying an established position - the doctrinal research into specific fields of law ('legal dogmatics'), sociology, history, legal philosophy and legal theory, as well as the "auxiliary legal sciences" ${ }^{4}$ - critical jurisprudence has appeared in recent decades, the methodological status of which has not been sufficiently explained yet. It seems to be more than just an influential current within postmodern legal theory (philosophy of law). This is because it has an ambition to comprehensively review legal phenomena from a specific ontological and epistemological point of view, suggesting a completely new methodology (within legal science). Leaving the question open for now whether critical jurisprudence should be regarded as an independent sub-discipline of jurisprudence or a deconstructive alternative to all the previous legal sciences, ${ }^{5}$ we would like to discuss its ontological presuppositions in this article.

In this paper, we use the concept of "ontological presuppositions"6 without losing sight of the fact that the way we use this concept entails certain simplification. Some of the presuppositions discussed below are assumptions from the borderline of ontology, epistemology, philosophy of science and political theory. The more metatheoretical status of these presuppositions will be indicated below, but for the clarity of the argument, given that these assumptions are related to the sphere of existence - legal phenomena, the functioning of the social and political order - we will retain the term used in the title of this article.

We claim that in the division into "legal doctrine" (Rechtslehre) and "legal science" (Rechtswissenschaft), as proposed by T. Pietrzykowski, critical jurisprudence is situated on the side of the latter, along with traditional sociology of law, legal history, philo-

4 According to textbook approaches, auxiliary legal sciences commonly include legal logic, forensic science, criminology, victimology and forensic medicine. These sciences derive methodology and (partly) the object of research from other (often exact) sciences, however, while cooperating with jurisprudence.

5 It should be pointed out that many representatives of critical legal studies, especially western ones, refrain from creating a positive methodology, a positive body of texts and tools that would establish a new science in a hard way (precisely in ontological terms). We believe that such an approach should be abandoned, hence laying the foundation for a dialogue between critical legal studies and traditional legal sciences, even if they are - prima facie - in an insurmountable conflict.

6 R. Mańko, W stronę krytycznej filozofii orzekania. Polityczność, etyka, legitymizacja, Łódź 2018. 
sophy of law and legal theory. ${ }^{7}$ Therefore, we use interchangeably the terms: "critical jurisprudence", "critical legal theory" and "critical legal studies". Critical jurisprudence is supposed to be methodologically syncretic ${ }^{8}$ in nature because it crosses through the traditional subdisciplinary divisions within legal sciences, frequently using the achievements of theory and philosophy, as well as sociology and sociological history of law in order to influence the findings of doctrinal legal research (legal dogmatics), though not necessarily sharing their specific methodology. What is more, it can even be said that critical jurisprudence is purposefully "adisciplinary", "post-disciplinary" or "interdisciplinary", 9 considering any strict divisions between legal disciplines as a relic of past scientific ideologies or cognitive and methodological assumptions. This way, critical jurisprudence becomes a new quality within legal research with other claims than the above-mentioned traditional currents and variations. Critical jurisprudence is undoubtedly characterised by a specific, syncretic methodology that is distinct from the classical one and is eternally in statu nascendi $i^{10}$ and characterised by a specific (emancipatory) goal of the research. ${ }^{11}$ Looking at the problem from a different, more classical point of view, we can say that we are dealing rather with "anti-methodology", with scientific anti-fundationalism, which questions the reasonability of efforts to look for the ontological basis of any phenomena that are under research (as well as the basis of the research programmes themselves). ${ }^{12}$ In this approach, critical jurisprudence will share only a vaguely conceptualised subject of research with classical legal studies, recognising it as a multidimensional phenomenon. It should be pointed out that J. Wróblewski or K. Opałek,

7 T. Pietrzykowski, Naturalizm i granice nauk prawnych. Esej z metodologii prawoznawstwa, Warszawa 2017, pp. 31-44.

$8 \quad$ R. Mańko, $W$ stronę..., p. 75.

9 For more see for instance: J. Łakomy, Interdyscyplinarność $i$ integracja zewnętrzna nauk prawnych w świetle postmodernistycznej krytyki, "Archiwum Filozofii Prawa i Filozofii Społecznej” 2011, 1, pp. $29-45$.

10 The term "methodology" obviously is used sensu largissimo here, referring to the thesis about the desired method of conducting research, even if these theses - as in the case of critical legal studies - highlight a sort of "anti-methodology" based on the assumption on anti-fundationism. For more on the methodology of critical legal studies, see for instance: A. Sulikowski, Idee i metody wspótczesnych krytycznych studiów nad prawem, "Przegląd Prawa Publicznego" 2015, 7-8.

11 As correctly pointed out by A. Sulikowski and K. Otręba, a critical approach in jurisprudence "requires combining the description and postulate, explanation and struggle, research and emancipation" (A. Sulikowski, K. Otręba, O potrzebie studiów krytycznych nad prawem konstytucyjnym, "Państwo i Prawo" 2017, 3, p. 5). See also: A. Sulikowski, Prawa a ideologia. Prawa jednostki z perspektywy krytycznej myśli prawniczej i społecznej (wybrane zagadnienia), "Roczniki Nauk Społecznych" 2015, 4, p. 19. Cf. P. Skuczyński, Typy myśli krytycznej w prawoznawstwie. Od krytyki poznania do walki o uznanie, [in:] T. Bekrycht et al. (eds.), Integracja zewnętrzna i wewnętrzna nauk prawnych, Vol. 1, Łódź 2014, p. 134. See also R. Mańko, W stronę..., p. 77.

12 Cf. P. Feyerabend, Przeciw metodzie, Wrocław 1996. 
writing about the multidimensionality of studies on law, remained within traditionally understood ontologies and epistemologies and therefore considered these dimensions to be factually or at least epistemically separate. ${ }^{13}$ However, in critical jurisprudence, as a result of its methodological syncretism, we can rather speak, as mentioned above, of post-disciplinarity ${ }^{14}$ instead of harmony of many different research perspectives.

The goal of this article is to consider ontological presuppositions ${ }^{15}$ of critical jurisprudence, understood as the social ontology assumptions ${ }^{16}$ that are necessary to be able to speak in a given case of critical jurisprudence, and hence as the ones that are crucial for its very identity. ${ }^{17}$ An auxiliary means for such findings will be to refer to the writings of representatives of critical legal studies, both foreign and Polish, to determine based on the reconstructed, sometimes tacit assumptions what their ontological presuppositions in the area of social ontology are. At the same time, we are fully aware that researchers classified as critical jurists internally differ from each other, and therefore it is often very difficult to establish the "lowest common denominator", also ontological one, appropriate for the given current. The author of one of the best-known works devoted to postmodern legal theory, Gary Minda, writes in great detail about the philosophical foundations of the movement of critical

13 W. Lang, J. Wróblewski, S. Zawadzki, Teoria państwa i prawa, Warszawa 1986, p. 32. For more about the genesis of the concept of methodological multidimensionality of jurisprudence and law approaches as complex structures, see: ibidem, p. 33; K. Opałek, Problemy metodologiczne nauki prawa, Warszawa 1962, p. 109. Jerzy Wróblewski sees the genesis of multidimensionality in the concept of law as an emotional-imperative-attributive experience. Law in this concept was the ideal equivalent of this experience in the form of a norm and a real equivalent in the form of social behaviour. Jerzy Lande as a student of Leon Petrażycki was under a clear influence of his psychological concepts of law. A lot about the historical and philosophical origins of the concept of multidimensionality as a response to the criticism of very unilateral approaches to law in legal positivism at the beginning of the $20^{\text {th }}$ century was written by Kazimierz Opałek in his later work, see: K. Opałek, J. Wróblewski, Prawo. Metodologia, filozofia, teoria prawa, Warszawa 1991, p. 55. An analysis of the issue of ontological complexity of law is conducted by Jerzy Wróblewski, see: ibidem, p. 87.

14 Cf. P. Nyström, Disciplinarity, Inter-disciplinarity and Post-disciplinarity: Changing Disciplinary Patterns in the History Discipline, [in:] La interdisciplinaridad y la transdisciplinaridad en la organización de conocimiento científico, León 2007.

15 Cf. M. Smolak, Presupozycje ontologiczne tekstu prawnego, "Ruch Prawniczy, Ekonomiczny i Socjologiczny" 2011, 4, who defines this concept as a set of assumptions on social reality. Marek Smolak referred this concept for the assumptions underlying the legal text, influencing its understanding, and to a large extent the "extra-text" world. In our view, ontological presuppositions are assumptions that make a specific "reflection" institutionalised into a scientific discipline possible. Of course, presuppositions underlying legal texts are in a way indirectly important also for us.

On the identity of critical jurisprudence see e.g. R. Mańko, W stronę..., pp. 21-29. 
legal studies. ${ }^{18}$ In the further part of the book, he discusses, for instance, feminist jurisprudence ${ }^{19}$ and critical race theory, ${ }^{20}$ which - from our point of view - can undoubtedly be classified as broadly understood critical legal studies. However, they feature partially different ontological presuppositions, emphasising particular specific antagonisms (sexual, racial ones) at the expense of fundamental economic (class) antagonism. ${ }^{21}$

Therefore, the goal of the article is mixed because, on the one hand, it has a reconstructive purpose, aimed at reconstructing assumptions (also the tacit ones) adopted by the actually existing critical legal studies (sociological moment), and, on the other hand, it has a projective goal in the form proposed assumptions whose fulfilment should be a prerequisite for including a particular scientific statement in the current of critical legal studies instead of the traditional varieties of this science (theoretical moment). ${ }^{22}$ It is also obvious that the social ontology itself does not exhaust all the assumptions that have to be made to speak of an opportunity to practice a given form of scientific reflection (or to classify a specific statement as a given type or subgenre, in casu of critical jurisprudence); however, we think that the reconstruction of this particular aspect is a convenient starting point for further discussion on critical legal theory, and it can also be of major importance for the formulation of theoretical assumptions of application research (applying the assumptions of critical legal studies to specific branches of law), e.g. critical analyses of doctrinal writings and case-law, in particular in view of their relationship with politics. ${ }^{23}$

18 G. Minda, Postmodern Legal Movements. Law and Jurisprudence at Century's End, New York 1995, pp. 106-127.

19 Ibidem, pp. 128-148.

$20 \quad$ Ibidem, pp. 167-185.

21 Cf. ibidem, pp. 106-185; I. Ward, An Introduction to Critical Legal Theory, London-Sydney 1998, pp. 161 et seq.

22 Of course, there are many works featuring a significant critical potential, sharing some of the ontological presuppositions discussed below, or sharing them in a limited scope. Inclusion thereof in critical legal studies is quite problematic, cf. for example the excellent reconstructive work of Wrocław philosophers of law, Przemysław Kaczmarek and Paweł Jabłoński, in which they explain the sociology of law of Leon Petrazycki, Florian Znaniecki, Jacek Szmatka and Piotr Sztomka: P. Kaczmarek, P. Jabłoński, Granice władzy prawniczej w perspektywie polskiej tradycji socjologicznej, Kraków 2017. In the introduction to this monograph, Kaczmarek and Jabłoński propose an original conceptualisation of the limits of legal power, identifying four of their determinants: 1) political and legal culture; 2) legal text; 3) legal culture; 4) subjective factors. Such an approach to the limits of legal discretionary power (or, in other words, the limits of political nature of legal power) assumes that the authors, while synthesising the most important works of Polish sociology of law, to a certain extent accept ontological presuppositions contained in this article.

23 See recently, for example: H. Dębska, T. Warczok, The Social Construction of Femininity in the Discourse of the Polish Constitutional Court, [in:] R. Mańko et al. (eds.), Law and Critique in Central Europe: Questioning the Past, Resisting the Present, Oxford 2016; R. Mańko, Symbolic Violence in Technocratic Law 
The presuppositions indicated in this article are intended to be the minimal and necessary catalogue, i.e. the inclusion of a specific scientific statement in the current of critical legal studies is possible only if the author of a given statement accepts them all, explicitly or implicitly. At the same time, however, the acceptance (explicit or implicit) of the indicated ontological presuppositions is not, in itself, a sufficient condition to classify a specific scientific statement in the current of critical legal studies. This is because critical legal studies are defined in detail not only by its social ontology assumptions, but also by at least two other elements, which, although closely related to the presuppositions outlined here, do not necessarily result from them. These are, firstly, methodological assumptions that place critical legal studies in the "hermeneutics of suspicion" and, secondly, the emancipatory goal underlying the praxeological assumptions of critical legal studies. ${ }^{24}$ Therefore, it is possible that a certain scientific statement admittedly shares its ontological presuppositions with critical jurisprudence, but it does not accept either its methodological assumptions or - which seems much more likely in practice - does not share the emancipatory goal underlying any critical theory (science), or even has completely opposite goals, such as the current of conservative crits, accurately described by A. Sulikowski. ${ }^{25}$

Moreover, the catalogue of presuppositions is not closed in the sense that specific currents of critical jurisprudence can take a number of additional presuppositions proper to them. This applies both to universal presuppositions (e.g. the ones on the ideology and its role in the creation, interpretation and application of law) ${ }^{26}$

and Attempts at Its Overcoming: Politicisation through Humanization?, "Wrocławskie Studia Erazmiańskie" 2017, 11; W. Zomerski, Krytyczna analiza dyskursu sądowego dotyczącego prawnej sytuacji osób homoseksualnych w świetle art. 18 Konstytucji RP, "Archiwum Filozofii Prawa i Filozofii Społecznej" 2017, 2.

24 Cf. B. Leiter, The Hermeneutics of Suspicion: Recovering Marx, Nietsche and Freud, The University of Texas School of Law. Public Law and Legal Theory Working Paper No. 72/2005, accessible at: http://ssrn.com/abstract=691002 (access: 31.01.2018). Cf. the comment by A. Sulikowski, recognising the key role of the thought of Marx, Nietzsche and Freud for critical legal studies (A. Sulikowski, Prawa a ideologia..., p. 19).

25 A. Sulikowski, Afirmatywna amnezja i konserwatywni 'crits'. Kilka uwag o kondycji krytycznej myśli prawniczej w Europie Środkowej i Wschodniej, "Archiwum Filozofii Prawa i Filozofii Społecznej" 2014, 1.

26 Cf. D. Šulmane, Ideology, Nationalism and Law: Legal Tools For An Ideological Machinery in Latvia, "Wrocław Review of Law, Administration and Economics" 2015, 1; M. Stambulski, The Critique of Ideological Legal Reason, "Wrocław Review of Law, Administration and Economics" 2015, 1(1); W. Zomerski, Ideology In Modern Times: Three Ideological Lies Behind Universal Human Rights, "Wrocław Review of Law, Administration and Economics" 2015, 1; M. Škop, The Importance of Being a Linguist: Critical Legal Thought in Central Europe, [in:] R. Mańko et al. (eds.), Law and Critique in Central Europe: Questioning the Past, Resisting the Present, Oxford 2016, pp. 40-41; R. Mańko, Ideology and Legal Interpretation: Some Theoretical Considerations, [in:] K. Torgāns et al. (eds.), Constitutional Values in Contemporary Legal Space, Vol. 1, Riga 2016; W. Zomerski, Krytyczna analiza... 
and to the local ones (e.g. on the identification of social groups subject to domination and requiring emancipation, or on the nature and scope of conflicts and interests specific to defined groups).

\section{Assumption of the political nature of the social world}

The seemingly first and fundamental assumption on the social ontology shared by all currents of critical legal science, from classical ones (the American movement: Critical Legal Studies) to numerous variations created later (critical race theory, feminist jurisprudence), and even the currents that are on the margins of the mainstream of critical legal studies (like critical legal sociology referring to the methodological assumptions of P. Bourdieu), is an assumption on the political nature of the social world. ${ }^{27}$ The term "political" should be understood here according to C. Schmitt, ${ }^{28}$ C. Mouffe and E. Laclau ${ }^{29}$ and the authors referring to them (like S. Žižek, A. Sulikowski ${ }^{30}$ or M. Paździora and M. Stambulski ${ }^{31}$ ), not as a simple relationship with politics or determination through politics, but as a dimension of an inalienable conflict within society. ${ }^{32}$ The assumption of the political nature of the social world means that conflict is inscribed in all social phenomena and cannot be definitely eliminated $^{33}$. Therefore, society is prone to conflicts, and it is necessary to develop mechanisms for their institutionalisation, but it is not possible to eliminate them (it is impossible to create a harmonious society that is devoid of any conflicts ${ }^{34}$ ). Specific types of conflicts are the expansion of the thesis on the political nature of

27 For the issue of law and political nature, see for instance: C. Douzinas, R. Warringron, S. McVeigh, Postmodern Jurisprudence. The Law of Text in the Texts of Law, London-New York 1991; C. Douzinas et al. (eds.), Politics, Postmodernity and Critical Legal Studies. The Legality of the Contingent, London-New York 1994; C. Douzinas, A. Gearey, Critical Jurisprudence. The Political Philosophy of Justice, Oxford-Portland 2005; M. Stone et al. (eds.), New Critical Legal Thinking. Law and the Political, Abingdon 2014.

28 C. Schmitt, Pojęcie polityczności, [in:] idem, Teologia polityczna i inne pisma, Warszawa 2012.

29 C. Mouffe, E. Laclau, Hegemonia i socjalistyczna strategia. Przyczynek do projektu radykalnej polityki demokratycznej, Wrocław 2005.

30 A. Sulikowski, Trybunat Konstytucyjny a polityczność. O konsekwencjach upadku pewnego mitu, "Państwo i Prawo" 2016, 4.

31 M. Paździora, M. Stambulski Co może dać nauce prawa polityczność? Przyczynek do przyszłych badań, "Archiwum Filozofii Prawa i Filozofii Społecznej" 2014, 1, pp. 55-56; M. Stambulski, Polityczność jako etyka polityczna prawa [in:] M. Dudek et al. (eds.), Aksjologiczny wymiar prawa, Kraków 2015.

32 C. Mouffe, Polityczność, Kraków 2015.

33 R. Mańko, W stronę..., pp. 147-151.

34 Ibidem, p. 40. 
the social world. It seems that the consensus of critical jurisprudence covers the statement that one of such conflicts is a class conflict (and therefore a conflict of an economic nature). ${ }^{35}$ On the other hand, what is more controversial is the extent to which this conflict is of a fundamental importance (the differences between the classical current, which refers directly to the assumptions of Marxism, and the later currents, which stress the importance of cultural conflicts, are highlighted here) and the question which other conflicts are significant from the perspective of critical jurisprudence and which are insignificant, and therefore negligible in the analyses carried out by the representatives of the discussed current. ${ }^{36}$

The political nature assumption differentiates critical legal theory from those currents of jurisrpudence that assume that conflict is beyond their scope of interests (doctrinal legal research, classical positivism) and those currents that recognise the existence of conflicts, but assume that it is possible to solve them by means of a properly developed framework for institutionalised social dialogue (liberal currents in legal philosophy, e.g. J. Habermas). ${ }^{37}$ The assumption that conflict is a basic and inherent dimension of social ontology, assimilates critical jurisprudence with certain currents that cannot be included in it because of their non-emancipatory or even counter-emancipatory nature (e.g. C. Schmitt's philosophy of law).

The assumption of the political nature of the social world implies the necessity of accepting further ontological presuppositions, and, in particular, the assumption that it is possible to identify specific social groups that are in a conflict of interest. As mentioned above, these groups can be identified according to various criteria, with the determinant being the assumption on a specific nature of the conflict. Therefore, starting from the assumption of the economic nature of the conflict, we will identify social classes (based on the ownership of the means of production - the class of owners of means of production, traditionally defined with a French-derived term "bourgeoisie", and the class of employees, traditionally referred to as the working class). It is, however, possible to identify other social groups based on economic criteria, and the thesis on the two-class system is hardly regarded as an indispensable foundation of critical legal studies. The adoption of different criteria for identifying conflicts will result in the identification of different groups having their interests and being in conflicts with these interests, such as cultural, racial or moral minorities. ${ }^{38}$

\footnotetext{
35 Ibidem, pp. 27, 79.

36 Cf. A. Sulikowski, K. Otręba, op. cit., p. 7.

37 Cf. R. Mańko, W stronę..., pp. 56, 61, 151, 249.

38 P. Skuczyński, Typy myśli krytycznej..., pp. 146-147.
} 
The assumption that conflicts are permanent also results in the assumption that one of the parties to the conflict always has an advantage over the other - i.e. that in the social world there is domination of one group over the other. The nature of the domination is, at the same time, a derivative of the nature of the conflict (economic domination, cultural domination).

Apart from identification of specific groups as social entities, the assumption of the political also entails recognising the existence of the category of interest as something that can be predicated of as existing socially. For the needs of critical jurisprudence, this interest is defined broadly not only as an economic interest, but also as an interest in the form of a claim to recognition (the Hegelian Anerkennung), ${ }^{39}$ cultural interest (e.g. using one's own language) or a broadly understood personal interest. The acceptance of the existence of interest as a category significant on the basis of social ontology presupposed by critical legal studies is in close connection with the emancipatory goals of this science whose achievement is to be possible only through the implementation of certain interests that cannot be implemented under conditions subject to critique (e.g. interests of the working class, interests of cultural, racial and lifestyle minorities). ${ }^{40}$

Concluding this part of the paper, it should be pointed out that the social ontology presupposed by critical jurisprudence assumes the fundamental nature of the social conflict dimension (its political nature), which, in turn, presupposes the existence of specific identifiable groups that are in conflict with each other, and the interests that can be attributed to the groups whose full implementation (in the case of dominated groups) is convergent with the emancipatory goal of critical legal studies, i.e. the striving for the liberation of specific groups from (economic and cultural) domination.

\section{Assumption on the social construction of the social world}

The second fundamental element of social ontology presupposed by critical jurisprudence seems to be the thesis on social constructionism, i.e. on the social construction of the social world. ${ }^{41}$ In other words, for critical legal theory, social ontology is not something given once and for all and subject to only passive analysis, but

\footnotetext{
39 Ibidem, p. 147.

40 R. Mańko, W stronę..., s. 42.

41 The classical approach to this thesis can be found in: P.L. Berger, T. Luckmann, Społeczne tworzenie rzeczywistości, Warszawa 1983.
} 
something that is constructed socially and can be subject to change, ${ }^{42}$ which can also be effected by engaged researchers. ${ }^{43}$ This thesis is succinctly reflected by the $11^{\text {th }}$ thesis on Feuerbach, according to which the goal of philosophy is not so much to interpret the world as to change it. Without going into details of the issue whether indeed this thesis meaningfully reflects the tasks of philosophy in general or whether it should be referred only to critical philosophy, it should be assumed that the assumption of social construction (production and reproduction) of social relations is a presupposition sine qua non of critical legal studies, which is due to its emancipatory nature. Critical legal studies presuppose that law and the relations regulated by it are effects of the social construction of reality and as such they can be subject to critique aimed at changing them. ${ }^{44}$ Otherwise, the critique of law, which is the basic discursive tool of critical legal studies, would be pointless, and the assumption of its emancipatory goal would have to be removed, which would simultaneously deprive critical legal studies of its essence. At the same time, one should emphasise the important delegitimisation consequences adopted by critical legal studies, which undoubtedly tend to weaken the authority of traditional legal sciences and their methodology, in particular - doctrinal legal research (legal dogmatics) and its research method, focused on formal and conceptual, rather than political, analysis of legal phenomena.

The thesis in question is shared by critical legal studies with most of contemporary humanities, in particular with the currents prevailing nowadays in sociology, philosophy and cultural studies. In the sociology of law, this thesis is taken up in particular by the current of critical sociology inspired by the though of P. Bourdieu. ${ }^{45}$

On the other hand, this assumption clearly distinguishes critical jurisprudence from legal dogmatics, ${ }^{46}$ for which a legal text is the main point of reference and is

42 R. Mańko, W stronę..., s. 38.

43 Of course, the acceptance of the thesis on the social construction of reality does not automatically imply the acceptance of the attitude involved. Although the creators of social constructionism, Berger and Luckmann, stressed the contingency of a particular organisation of society, they did not call for emancipatory changes, but chose description instead of critical involvement. The same applies to Artur Kozak, who, while accepting the thesis of social constructionism in relation to the legal community, even called for its strengthening in relation to other institutional sub-worlds (politics, economy) instead of emancipation of the latter from the legal sub-world. See: A. Kozak, Granice prawniczej władzy dyskrecjonalnej, Wrocław 2002, in particular the Chapter entitled "Instytucjonalizacja jako kreowanie rzeczywistości".

$44 \quad$ R. Mańko, W stronę..., s. 38.

45 Cf. a concise presentation of the basic assumptions on the critical sociology of P. Bourdieu (in relation to the juridical) in: H. Dębska, Wtadza, symbol, prawo. Społeczne tworzenie Trybunatu Konstytucyjnego, Warszawa 2015, p. 15-71; eadem, Prawo jako pole (ujęcie modelowe), "Państwo i Prawo" 2016, 9.

46 R. Mańko, W stronę..., s. 39. 
not treated as something that science itself could change, but as something that it intends to understand usually by assuming that it has one correct meaning (which can be "disputed in the doctrine"). ${ }^{47}$ Legal dogmatics ${ }^{48}$ admittedly recognises that a legal text is a product of the legislator (and thus a social construct), but, contrary to critical legal studies, it treats the text of law as a "dogma" and thus denies its constructivist nature, treating the social construct as an axiom rather than as a mutable object of critique. ${ }^{49}$ As for the relationship between critical legal studies and philosophy of law, it should be pointed out that some of the currents of the latter also assume the social construction of law and the relations regulated by law - such as juricentrism ${ }^{50}$ created by A. Kozak, as well as the currents of broadly understood legal pragmatism - while other support the view that it is possible to discover and describe truths and rules governing the social world, which are not produced socially, but are given from outside, and thus determine the social world. The older currents of legal philosophy adopting this assumption include jusnaturalism, and the newer one include currents inspired by exact sciences, in particular cognitive science and classical economics (economic analysis of law). This does not mean, of course, that jusnaturalists or advocates of the naturalisation of jurisprudence in the cognitive or economic fashion do not formulate critical remarks on the positive law, but the basis for these remarks is different than in critical legal studies - they result either from religious and ethical assumptions (like in the case of classical jusnaturalism) or from scientistic assumptions (as in the case of new naturalisation currents in jurisprudence - which can be defined as biologism or legal economism respectively). Critical jurisprudence differs to a great extent from both approaches, advocating strongly the view that its goal is not only to describe and interpret the social conditions of legal phenomena, but also to provide their fundamental critique as accidental social products and to exert influence to change them in a desired (i.e. emancipatory) direction.

47 We mean the tacit suppositions of most representatives of the scientific doctrine discourse. What is different in philosophical and legal models of doctrines, formulated in soft positivism, where it is purposefully made possible to co-create the content of law through its science, and so eo ipso also its change. Cf. e.g. M. Zirk-Sadowski, Prawo a uczestniczenie w kulturze, Łódź 1998; J. Leszczyński, Pozytywizacja prawa w dyskursie dogmatycznym, Kraków 2010. Moreover, it should be pointed out that unscientific hermeneutics also accept that the object of cognition is co-created by the subject of cognition, however - in contrast to critical legal theory - critical and emancipatory goals do not result from it.

48 "Legal dogmatics" is a singular noun, at least as used in legal theory writings. See e.g. Aulis Aarnio, The Rational as Reasonable, Dordrecht 1987, p. 12 („legal dogmatics is...”).

49 R. Mańko, W stronę..., s. 39-40.

50 A. Kozak, Granice...; idem, Myślenie analityczne w nauce prawa i praktyce prawniczej, Wrocław 2012. 


\section{Assumption on paninterpretationism}

The third important element of social ontology, presupposed by critical legal studies, is the assumption on social paninterpretationism, according to which all social phenomena, including, in particular, legal texts and other legal phenomena, are subject to interpretation and cannot be perceived by social actors before or beyond interpretation. ${ }^{51}$ Paninterpretationism is a view according to which every instance of cognition is relative to the perspective of the cognising subject. In other words, any cognition is inherently a form of interpretation, whereby there is no cognition free from any perspective, i.e. providing a "view from nowhere", as metaphorically put by philosopher Thomas Nagel. ${ }^{52}$ As the American pragmatist Richard Shuster$\operatorname{man}^{53}$ notes, according to painterpretationism, "we see everything through an interpretative veil or angle (...) we do not merely see everything through interpretation but everything is in fact constituted by interpretation. In other words, there is no real (and certainly nothing real for us) that is not interpreted" ${ }^{54} \mathrm{R}$. Shusterman sees the origins of such a view in Nietzsche's perspecticism, and its fullest expression in contemporary philosophy of interpretation of the American neopragmatist Stanley Fish. It is the latter who, in his famous essay, in which he argues with Ronald Dworkin, ${ }^{55}$ states that even in an unthinking, simple, initial act of understanding "the interpretation has already done its work". 56

This assumption is significant because it determines - just like the assumption on social constructionism - the status of entities belonging to the social ontology presupposed by critical jurisprudence. It is because these entities themselves - just like the above-mentioned conflicts, classes, interests - are subject to interpretation, and they can be subject to examination by critical jurisprudence only after their

51 R. Mańko, W stronę..., s. 67.

52 T. Nagel, Widok znikąd, Warszawa 1997.

53 R. Shusterman, Estetyka pragmatyczna. Żywe piękno i refleksja nad sztuka, Wrocław 1998, p. 115 (Chapter 4: "Interpretacja i rozumienie"). Although in this chapter Richard Shusterman criticises the extremes of the pan-interpretationist view, his reconstruction seems to be reliable, consistent and holistic.

$54 \quad$ Ibidem, pp. 115-116.

55 For more on the polemics of Ronald Dworkin with Stanley Fesh see e.g.: J. Łakomy, Spory wokót wykładni prawa między nowoczesnościa a ponowoczesnością. Na przykładzie debaty Dworkina z Fishem, [in:] A. Samonek (ed.), Teoria prawa między nowoczesnościa a ponowoczesnościa, Kraków 2012; idem, The Space of the Political in Legal Interpretation (Some Remarks on the Dworkin-Fish Debate), [in:] P. Bieś-Srokosz, J. Srokosz, R. Mańko (eds.), Law, Space and the Political: An East/West Perspective, Częstochowa 2017.

56 S. Fish, Working on the Chain Gang: Interpretation in the Law and in Literary Criticism, "Critical Inquiry" 1982, 9, p. 204. 
interpretation. It can even be argued that the mere cognition of specific phenomena in a scientific study is already their interpretation, filtered through cognitive categories (episteme), shaped in terms of the location in the structure of social conflicts.

Obviously, all legal phenomena, in particular texts (statutory law, precedents) are also subject to interpretation. Adopting the assumptions of paniterpretationism, critical jurisprudence assumes that everything is an interpretation which leads to the merging of the category of cognition of the sources of law in the traditional sense with other traditional categories, such as fact finding or legal interpretation. Importantly, interpretation is a per se creative process for critical jurisrpudence, in other words, the subject of cognition (e.g. a judge) co-creates the object of cognition, which is the meaning of a legal text. In this sense, at the level of social ontology, critical jurisprudence presupposes the existence of meanings produced in the process of interpretation and the existence of texts themselves, which, however, are not mere material sequences of characters and have no meaning independent of the process of interpretation. Such phenomena of legal culture as textualism (in the United States) or linguistic interpretation of a provision (in Poland) are only forms of interpretation and are, in principle, equally legitimate methods of reading texts as the methods competing with them, such as teleological, dynamic and other interpretations.

The presupposition on social interpretation can be developed further, by introducing assumptions on the reality of ideology whose existence in the social ontology is sometimes located in social consciousness (classical thesis about ideology as false consciousness ${ }^{57}$ ), or in social practices (Žižek-Sloterdijk's thesis about the cynical subject of ideology). ${ }^{58}$ Nevertheless, it seems that more elaborate presuppositions on the phenomenon of ideology - as a form of social existence - are not indispensable for critical jurisprudence as such, and therefore do not belong to its essence, which, however, does not mean that they cannot be a helpful tool for the critique of law as part of certain variants of this science, which take on the key role of ideology in creating and interpreting social reality, including socially constructed legal reality. ${ }^{59}$ Nonetheless, it seems that the problems pertaining to ideology should

57 Cf. H. Dębska, Law's Symbolic Power: Beyond The Marxist Conception of Ideology, "Wrocław Review of Law, Administration and Economics" 2015, 1, pp. 5-6.

58 S. Žižek, The Sublime Object of Ideology, Londyn 2008, s. 30. Cf. R. Mańko, Koncepcja interpelacji ideologicznej a krytyczny dyskurs o prawie, "Archiwum Filozofii Prawa i Filozofii Społeczne" 2004, 8, p. 42 .

59 For a broader treatment see: R. Mańko, W stronę..., p. 47-62. 
be placed among the methodological assumptions of critical legal studies, and not necessarily as part of its ontological presuppositions. ${ }^{60}$

\section{Assumption on the existence of epistemic communities}

Assumptions on the social construction of reality and paninterpretationism imply an assumption on the existence of epistemic communities within which intersubjective meanings are produced. ${ }^{61}$ For critical legal studies, a legal community is, apart from its political functions (in the regulation of social conflicts) always already an epistemic community, giving sense to legal texts (interpretation of law) and performing the juridical classification of social phenomena in the application of law. ${ }^{62}$ The legal community obviously competes with other communities in a given society, and there are also conflicts within the community itself (struggles for hegemony) and between communities. This way, the assumption on the existence of epistemic communities, which is a derivative of the assumption of interpretationism, is also closely connected with the assumption on the political- the latter extends to the interpretation community of lawyers.

The assumption on the existence of epistemic communities is common to critical jurisprudence and to some currents of the philosophy of law. However, it is foreign to legal dogmatics, according to which it is possible to cognize the actual meaning of norms and legal concepts that are an object of cognition independent of the jurists studying them. Also analytical legal theory considers that the cognition of its object of research is possible in an objective way, and is not a product of a specific epistemic community.

Defining the notion of epistemic communities is not an easy task. The most comprehensive understanding of this concept was proposed in the philosophical and legal literature by the aforementioned S. Fish, who, in his essay entitled How to Recognize a Poem When You See One, formulated a certain thesis on the meanings of texts that is important for understanding this concept, claiming that "meanings are the property neither of fixed and stable texts nor of free and independent readers but

60 Cf. A. Sulikowski, K. Otręba, op. cit., p. 6: "critical theorising is about proving the ideological and political nature hidden in pseudoneutral theoretical constructs dominating in social sciences (...)." Cf. also T. Pietrzykowski, op. cit., p. 127, who rightly emphasises the unmasking methodology underlying critical jurisprudence.

$61 \quad$ R. Mańko, W stronę..., p. 72.

62 Ibidem, p. 107-110. 
of interpretive communities that are responsible both for the shape of a reader's activities and for the texts those activities produce". ${ }^{63}$

This is a rather unusual view since it is situated beyond the dichotomy of the "subjectivity" and "objectivity" of interpretation (where in the former case the correctness of interpretation is a subjective matter determined by the individual point of view of the reader and in the latter case, it is determined by a certain external instance independent of the reader) and beyond the dichotomy of "textualism" and classically understood "intentionalism" (where the external instance deciding on the correctness of the interpretation is either the intention of the author of the text or the letter of that text). This is particularly important from our point of view because it is significantly associated with other ontological presuppositions identified by us, above all with the assumption on the political nature of the social world discussed above.

An epistemic community in the above-mentioned essay is perceived by S. Fish not as a "group of individuals" sharing a particular point of view, but as a "point of view" in itself, a "way of organising experience" that guides the reasoning and actions of a specific group of individuals. The strength of this point of view is so significant that Fish, when writing about the entities that share it, uses the terms "community property". ${ }^{64}$ Leszek Drong, one of the most diligent scholars of American neopragmatist theory, proposes his own definition of the epistemic community: "It seems more appropriate (...) to circumspectly define communities as a tool for description [emphasis added R.M. and J.t.] used to highlight the communal - i.e. socially and ideologically conditioned - nature of all cognition". ${ }^{65}$ The echoes of the concept of S. Fish's epistemic communities can be found in A. Kozak's juriscentric theory, which openly referred to Fish. Although neither Fish nor Kozak can be counted among the representatives of critical legal studies in the strict sense, ${ }^{66}$ it seems, however, that the assumption on paniterpretationism and the key role of epistemic communities (not only legal ones) is a sine qua non condition for practicing critically oriented jurisprudence. Interpretationism provides the basis for the critique of classical approaches to the application and interpretation of law, questioning the distinctions between the creation and application of law, and between fact-finding and legal interpretation. Blurring the dichotomy between fact-finding

\footnotetext{
63 S. Fish, Interpretacja, retoryka, polityka, Warszawa 2008, p. 81.

64 Ibidem, p. 251.

65 L. Drong, Od konwencjonalizmu do normatywizmu. Kilka uwag o ewolucji poglądów teoretycznoliterackich Stanleya Fisha, "ER(R)GO. Teoria. Literatura. Kultura" 2016, 12, p. 27.

66 Cf. A. Sulikowski, Konstytucjonalizm wobec „zemsty postmodernizmu”, "Przegląd Prawa i Administracji" 2017, 110, pp. 101-102.
} 
and evaluation (in legal, moral, political terms) opens new fields for the critique law-related phenomena. The concept of epistemic communities (together with the epistemological assumptions mentioned above) must be adopted and analysed in parallel with the assumption on the political nature of law, specifying it in more detail and complementing - by combining approaches derived from social ontology, philosophy of language, epistemology (paninterpretationism), sociology (law) and the theory of politics.

\section{Presuppositions on legal phenomena}

Ontological presuppositions of critical jurisprudence with regard to the phenomenon of law (legal science) are a derivative of the assumptions on the nature of the social world, discussed in the preceding sections. ${ }^{67}$ This is why the nature of the law presupposed by critical jurisprudence will be viewed by referring to the aforementioned assumptions concerning general social ontology. Firstly, it should be pointed out that the law from the point of view of critical jurisprudence is political in the sense that it regulates social conflicts, and also its concrete content is the expression of current (at a given place and time) views of social groups that are in political relationships with each other. In other words, the specific content of e.g. labour law, civil law or constitutional law not only regulates conflicts (which is admitted by most legal sciences), but also reflects the current state of ongoing conflicts (e.g. class, ethnic, belief, cultural ones). The law viewed in this perspective is, therefore, in a dialected relationship vis-à-vis the conflicts it regulates. Such an assumption is also indispensable in the context of the emancipatory goals of critical jurisprudence, which aims at influencing this dialectics for instance by revealing conflicts "frozen" in law and by attempting to change the law so as to change the balance of power (economic and social one). In this sense, paraphrasing Clausewitz, one can say that critical jurisprudence is politics implemented by "other" (i.e. legal) means. A practical example of critical jurisprudence understood this way is 'radical lawyering', which is practised in the Anglo-Saxon countries by means of test cases, where radical lawyers deliberately incite a court dispute in order to produce a change in the law. ${ }^{68}$ Of course, the occurrence of such a phenomenon is conditioned by a number of boundary assumptions related to legal culture, such as the possibility of judicial creation

67 The question whether the social can and should be distinguished based on critical jurisprudence from the juridical is left open for now.

68 For more see: D. Kennedy, The Hermeneutic of Suspicion in Contemporary American Legal Thought, "Law and Critique" 2015, 25. 
of law (case law) or a specific social role of the legal community, in particular the courts.

Secondly, referring to the thesis on the social construct of reality, it should be pointed out that from the point of view of critical jurisprudence, law is a social construct. ${ }^{69}$ This ontological presuposition radically cuts off critical jurisprudence from all currents assuming that normativity results from ontology (e.g. C. Schmitt arguing that law is the shelter of society, and normality precedes normativity, or naturalistic approaches - classic jusnaturism or modern legal biologism and economism). Nonetheless, it paradoxically brings critical jurisprudence closer to classical forms of legal positivism, emphasising the voluntarism of law (law as an expression of the sovereign's will, not a derivative of any other natural or cultural phenomenon). Of course, this does not mean that law is created in isolation from social conditions; on the contrary, for critical jurisprudence, law is produced and reproduced in a specific social context, within a specific socio-economic setting, which - according to well-known mechanisms described long ago - ultimately determines its content. Therefore, the voluntarism of the law-maker (legislator, judge-activist ${ }^{70}$ ) is limited by their location within the structure of conflicts, as a result of which their freedom is not as great as it might prima facie seem to be. Nonetheless, what is most essential for critical jurisprudence is the dialectical moment, and hence the understanding of law in the dynamics of its relationships with the social world, and not only unilaterally as its derivative (which distinguishes critical jurisprudence from certain simplified interpretations of Marxism, according to which the law would only be a superstructure attached to the socio-economic base and entirely determined by that base). ${ }^{71}$

Thirdly, referring to theses on social interpretationism and epistemic communities, it should be pointed out that for critical jurisprudence the legal is, above all, a product of interpretation..$^{72}$ This is because there is no law without interpretation (nullum ius sine interpretatione), and interpretation is a product of an epistemic community which limits the interpreter acting in a specific social context, while the privileged status of certain interpretations and their precedence over interpretations occurs in the broader context of the political. This assumption, shared by a large part of contemporary currents in philosophy of law, clearly distinguishes between critical jurisprudence and legal dogmatics.

69 Cf. A. Sulikowski, K. Otręba, op. cit., p. 9: "Law is treated by legal critics as a multi-faceted set of social practices or as a product of discourses - organised around certain hierarchies and rules of speaking practices that themselves produce their object".

70 In the sense of: a judge engaged in judicial activism.

71 Cf. R. Mańko, W stronę..., pp. 62-66.

72 Cf. A. Sulikowski, K. Otręba, op. cit., pp. 9-10. 


\section{Conclusions}

The ontological presuppositions of critical jurisprudence, presented above, determine - in addition to its methodological assumptions - the specific character of this form of legal research, which distinguishes it from other legal sciences. It will not be an exaggeration to say that what is of major importance for critical jurisprudence is the political triad (conflict-domination-emancipation), and, therefore, the recognition of these phenomena as absolutely real and relevant to law. Other presuppositions seem to be auxiliary and derivative in relation to the assumption on law's political nature. The explicit formulation of the fundamental ontological presuppositions of critical jurisprudence makes it possible, on the one hand, to define the scope of research currents that can be included within that strand of legal science and, on the other hand, opens the opportunity to analyse the similarities and differences between critical jurisprudence and various other currents present in contemporary legal studies. Due to the approach of critical jurisprudence to the issues of disciplinarity, an in particular post-disciplinarity or integration of sciences as advocated by it, the conceptualisation of ontological presuppositions will also allow a more fruitful dialogue with representatives of other non-legal areas of research, in particular general philosophy, political philosophy, sociology or cultural theory. 